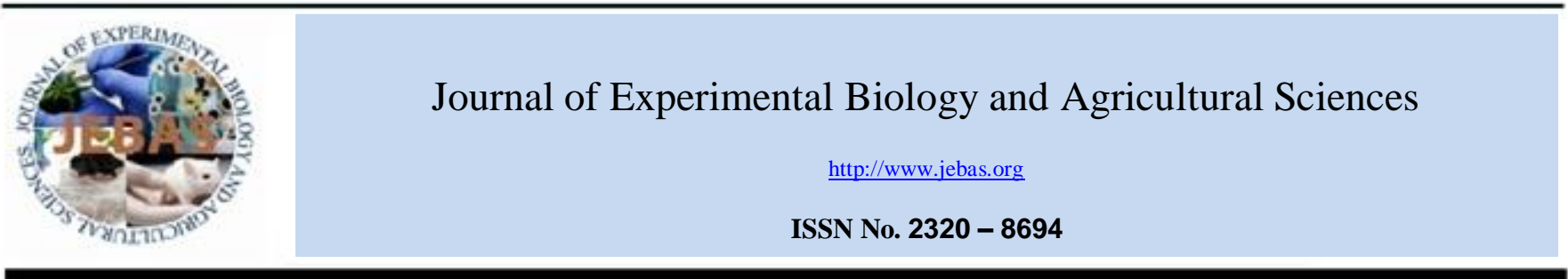

\title{
DEVELOPMENT OF Cytochrome $b$ BASED PCR AND EPIDEMIOLOGY OF B. gibsoni IN DOGS
}

\section{Lavanya $\mathrm{KV}^{1}$, Puttalakshmamma GC ${ }^{1}$, Yogisharadhya $\mathrm{R}^{2}$, Mohan $\mathrm{HV}^{1}$, Lakkundi JN ${ }^{1}$, GB Manjunatha Reddy ${ }^{2 *}$}

${ }^{1}$ Department of Veterinary Parasitology, Veterinary College, Hebbal, Bengaluru 560024.

${ }^{2}$ ICAR-National Institute of Veterinary Epidemiology and Disease Informatics (NIVEDI), Yelahanka, Bengaluru 560064.

Received - May 14, 2019; Revision - June 22, 2019; Accepted - July 14, 2019

Available Online - August 05, 2019

DOI: http://dx.doi.org/10.18006/2019.7(4).411.417

KEYWORDS
Babesia gibsoni
Cytochrome $b$ gene
Dog
Epidemiology
PCR
Phylogeny

\begin{abstract}
Canine babesiosis is emerging vector-borne disease of dogs and wild canids. The study aimed to develop PCR assay for detection of Babesia gibsoni and understanding epidemiology of disease in dogs. The cytochrome $b$ gene base PCR assay was developed with analytical sensitivity of detection up to $10^{-2}$ $(0.5 \mathrm{ng} / \mu \mathrm{l})$ of DNA. The specificity was confirmed by testing DNA from B. vogeli, Ehrlichia canis, Hepatozoon canis, and Dirofilaria repens. The thin blood smears examination revealed prevalence of $9.75 \%$ (32/328) for B. gibsoni. Whereas, with PCR the prevalence rate of $10.97 \%$ was recorded. There was significant association between vomition and dark yellow coloured urine with $B$. gibsoni infection. While age, breed, sex of the host and presence of ticks on animal body were not significantly associated with the occurrence of $B$. gibsoni infection. The sequence analysis showed $99.16-99.63 \%$ identity among themselves and 98.41 to $98.69 \%$ similarities with the published sequences of B. gibsoni. The phylogenetic analysis of Indian B. gibsoni isolates formed a single major group with other Asian countries indicating the monophyletic nature of B. gibsoni compared to other Babesia spp. Even though the vomition and yellow coloured urine combined with microscopic examination may help in diagnosis of B. gibsoni infection. Considering high analytical sensitivity and specificity of the cytochrome $b$ based PCR, we recommend confirmatory diagnosis with PCR before undertaking the treatment in suspected cases of B. gibsoni infection.
\end{abstract}

\footnotetext{
* Corresponding author

E-mail: gbmpatho@gmail.com ; gbm.reddy@icar.gov.in (G.B. Manjunatha Reddy)
}

Peer review under responsibility of Journal of Experimental Biology and Agricultural Sciences.

Production and Hosting by Horizon Publisher India [HPI] (http://www.horizonpublisherindia.in/).

All rights reserved.
All the articles published by Journal of Experimental Biology and Agricultural Sciences are licensed under a Creative Commons Attribution-NonCommercial 4.0 International License Based on a work at www.jebas.org.

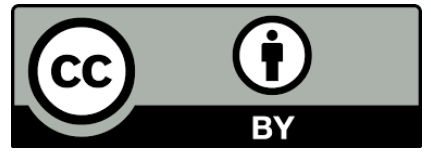




\section{Introduction}

Canine babesiosis is an emerging vector-borne haemoprotozoan disease caused by Babesia gibsoni and B. vogeli, in India. The disease is transmitted mainly by tick bite and rarely by dog bite, blood transfusion, transplacental route (Fukumoto et al., 2005). The acute form of the disease is typically associated with remittent fever, lethargy, haemolytic anemia, vomition, thrombocytopenia, haemoglobinuria, marked splenomegaly and hepatomegaly (Conrad et al., 1991; Boozer \& Macintire, 2003). In contrast, the chronic form may either lead carrier stage without clinical signs or recurrence of disease (Suh et al., 2017).

Routinely, the diagnosis of $B$. gibsoni infection is carried out by clinical signs combined with history and light-microscopic examination of blood smear (Solano-Gallego et al., 2016). But it's difficult to differentiate from other haemoprotozoan diseases with similar clinical picture (Suh et al., 2017). On the other hand, serological tests are used to detect circulating antibodies (Beugnet \& Moreau, 2015). However, due to high cross-reactivity and inability to differentiate acute from chronic infections limited their diagnostic application (Solano-Gallego et al., 2016). The more sensitive and specific diagnostic assay such as polymerase chain reaction (PCR) is being used for detection of B. gibsoni infection by targeting $18 \mathrm{~S}$ rRNA gene (Augustine et al., 2017).

In India, most of the B. gibsoni epidemiological studies were based on blood smear examination (Senthil Kumar et al., 2009; Wadhwa et al., 2011; Sahu et al., 2014) and very few references are available regarding the using of PCR assay targeting 18S rRNA gene (Abd Rani et al., 2011; Laha et al., 2014; Singh et al., 2014). The aim of the present study was to understand the risk factors and to evaluate the sensitivity and specificity of a cytochrome $b$ gene based PCR assay to detection of B. gibsoni and to understand the genetic diversity of $B$. gibsoni in dogs.

\section{Materials and methods}

\subsection{The study area}

The samples were collected from urban areas of Bengaluru $\left(12.97^{\circ} \mathrm{N} 77.56^{\circ} \mathrm{E}\right.$; area: $741 \mathrm{~km}^{2}$; elevation: $\left.900 \mathrm{~m}\right)$ and Hassan districts $\left(13.012^{\circ} \mathrm{N} 76.068^{\circ} \mathrm{E}\right.$; area: $26.52 \mathrm{~km}^{2}$; elevation: $\left.980 \mathrm{~m}\right)$. They lie in the southeast of the South Indian state of Karnataka, India. Both districts have a tropical savanna climate (Koppen climate classification Aw) with distinct wet and dry seasons. Bengaluru climate presents an average low temperature of $15.1^{\circ} \mathrm{C}$ (January) and with an average high temperature of $35^{\circ} \mathrm{C}$ (April).

\subsection{Samples}

A total of 328 dogs of different breeds and age groups from Bengaluru urban $(n=316)$ and Hassan districts $(n=12)$ were included in the present study. The blood samples were collected along with clinical history and risk factors. Two thin blood methanol fixed smears were prepared for each sample and stained with Giemsa for light microscopic screening of the B. gibsoni organisms (Bilwal et al., 2017).

\subsection{Primer design}

The primers were designed based on the B. gibsoni mitochondrial cytochrome $b$ (cytb) gene sequences available in GenBank database (AB685190; AB215096; AB685187; DQ287953; AB499087; KP666169; AB685184; AB685183 and AB685182) using Vector NTI advance 11 software. The primers BgcytbF (ATG TTG TCC TAT TTG GTT CC) and BgcytbR (TAT AAA CGC ATT CTA GCG C) were then evaluated for similarities against the GenBank database by means of BLASTn algorithm.

\subsection{Genomic DNA isolation}

The genomic DNA was isolated from the $200 \mu \mathrm{l}$ of anticoagulated blood of each dog using the DNeasy Blood and Tissue Kit (Qiagen GmbH, Hilden, Germany) as per manufacturer's protocol. The purity of genomic DNA was checked with spectrophotometer (Nano drop 2000C, Thermoscientific, USA).

\subsection{Standardisation of Bgcytb based PCR}

Three blood samples which were confirmed positive for $B$. gibsoni by microscopic examination as well as by $18 \mathrm{~S}$ rRNA based seminested PCR (Birkenheuer et al., 2003) were used as positive controls. The Gradient PCR for bgcytb gene was performed to optimize the annealing temperature by using known positive and negative DNA. An analytical sensitivity of the assay was determined based on the amplification of serially 10 -fold diluted DNA $(23.5 \mathrm{ng} / \mu \mathrm{l})$ of positive control showing parasitemia of $3.17 \%$. In order to compare the sensitivity of bgcytb based PCR with $18 \mathrm{~S}$ rRNA based PCR, the same serially diluted DNA $\left(10^{-1}\right.$ to $10^{-6}$ ) were subjected for genus specific PCR targeting $18 \mathrm{~s}$ rRNA (Birkenheuer et al., 2003). In order to check the analytical specificity, genomic DNA of Ehrlichia canis, Hepatozoon canis, Dirofilaria repens and B. vogeli were used as reference.

\subsection{Protocol}

PCR was performed in a final volume of $25 \mu$ l, containing $12.5 \mu \mathrm{l}$ of PCR master mix (DreamTaq ${ }^{\mathrm{TM}}$ Green PCR Master Mix (2x), Thermo Fisher Scientific), $7.5 \mu \mathrm{l}$ of nuclease free water (Thermo Fisher Scientific, Lithuania), $1 \mu \mathrm{l}$ of each forward and reverse primers $(10 \mathrm{pmol} / \mu \mathrm{l})$ and $3 \mu \mathrm{l}$ of template DNA. A non-template and negative control were included in each run. The amplification was performed with the following thermal profile; initial denaturation at $95^{\circ} \mathrm{C}$ for $5 \mathrm{~min}$, followed by 35 cycles of denaturation $\left(95^{\circ} \mathrm{C}\right.$ for $\left.1 \mathrm{~min}\right)$, annealing $\left(57^{\circ} \mathrm{C}\right.$ for $\left.1 \mathrm{~min}\right)$, and 
extension $\left(72^{\circ} \mathrm{C}\right.$ for $\left.1 \mathrm{~min}\right)$, and a final extension at $72^{\circ} \mathrm{C}$ for 7 min (Mastercycler®nexus, Eppendorf, Germany). All PCR products obtained were confirmed for amplification by electrophoresis in $1 \%$ agarose gel containing $0.2 \mu \mathrm{g}$ of ethidium bromide/ml. The gels were visualized using gel documentation system (Syngene, UK).

\subsection{Sequencing and phylogenetic analysis}

After gel electrophoresis, the specific 1070bp size amplicons were excised and the PCR product was purified using gel extraction kit (Thermo Fisher Scientific, Lithuania) by following manufactures protocol. The final elution's were sequenced from both ends by sanger's dideoxy chain termination method using forward and reverse primers (Eurofins Pvt. Ltd., Bengaluru). The sequences were subjected for alignment and phylogenetic tree was constructed using MEGAX (Kumar et al., 2018)

\subsection{Statistical analysis}

Association between the prevalence of $B$. gibsoni by PCR with various risk factors such as, age, breed, gender, fur length, tick infestation and clinical signs like fever, vomition and dark yellow colour urine carried out by Pearson's Chi-square $(\chi 2)$ test. The data was analysed by using statistical software program (Graphpad Prism). Values of $\mathrm{p}<0.05$ were considered significant.

\section{Results}

\subsection{Blood smear examination}

The Giemsa-stained blood smear examination revealed $9.75 \%$ prevalence rate $(32 / 328)$ for the B. gibsoni organisms. During examination of blood smears, the different forms such as signet ring, rod and anaplasma like forms of B. gibsoni were observed. Interestingly, atypical forms of B. gibsoni such as large ovoid to circular forms of B. gibsoni i.e., about half the diameter of the host cell were found and these were rare forms. Dividing stage and multiple organisms in one individual RBC has also been recorded.

\subsection{Molecular diagnosis (PCR)}

In analytical sensitivity, distinct amplicons were observed up to $10^{-2}(0.5 \mathrm{ng} / \mu \mathrm{l})$ dilution of template DNA (Figure 1). Further, in analytical specificity no amplification was observed with positive B. vogeli, H. canis, E. canis and D. repens DNA, which confirms the specificity of designed primers in the present study. After standardization, a total of 328 blood samples were screened by inhouse developed PCR assay targeting the complete coding sequence of B. gibsoni cytochrome $b$ gene. A total of $10.97 \%$ of dogs $(n=36 / 328)$ were positive for B. gibsoni as revealed by the amplification of $1070 \mathrm{bp}$ size amplicon, which were later confirmed by sequencing.

\subsection{Sequencing and phylogenetic analysis}

Three complete coding sequences of the cytochrome $b$ gene obtained were edited and submitted to GenBank (MK840539, MK840542 and MK840550). BLAST analysis of the sequences revealed 98.41 to $98.69 \%$ similar with the published sequences of B. gibsoni Asian genotype. The three sequences shared at 99.16 to 99.63\% identities among themselves. The phylogenetic analysis showed all the three Indian isolates grouped with B. gibsoni isolates from Japan and China forming single group (Gr-I Babesia of dogs). Within the Gr-I, the Indian isolates formed separate subgroup (Figure 2). The other babesia species affecting dogs formed separate group ( $\mathrm{Gr}-\mathrm{II}$ babesia of dogs) compared to other animal babesia species (Gr-III babesia of other animals). The genus babesia formed separate clade compared to genus theileria of the order piroplasmida (Figure 2). The nucleotide variations

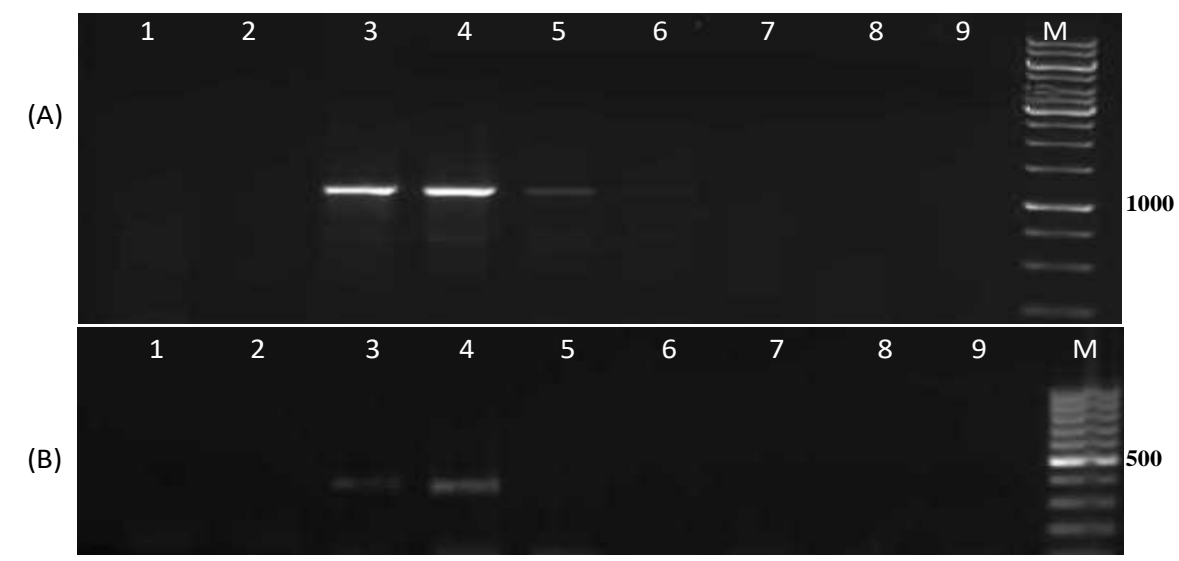

Figure 1 Analytical sensitivity of B.gibsoni-specific cytb (A) and18S rRNA (B) PCR: Lane1: No template control, Lane2: DNA from uninfected dog, Lane3: DNA from infected dog, Lane 4-9: Serial 10- fold dilutions of positive DNA $\left(10^{-1}\right.$ to $\left.10^{-6}\right)$ and Lane M: DNA ladder.

Journal of Experimental Biology and Agricultural Sciences http://www.jebas.org 


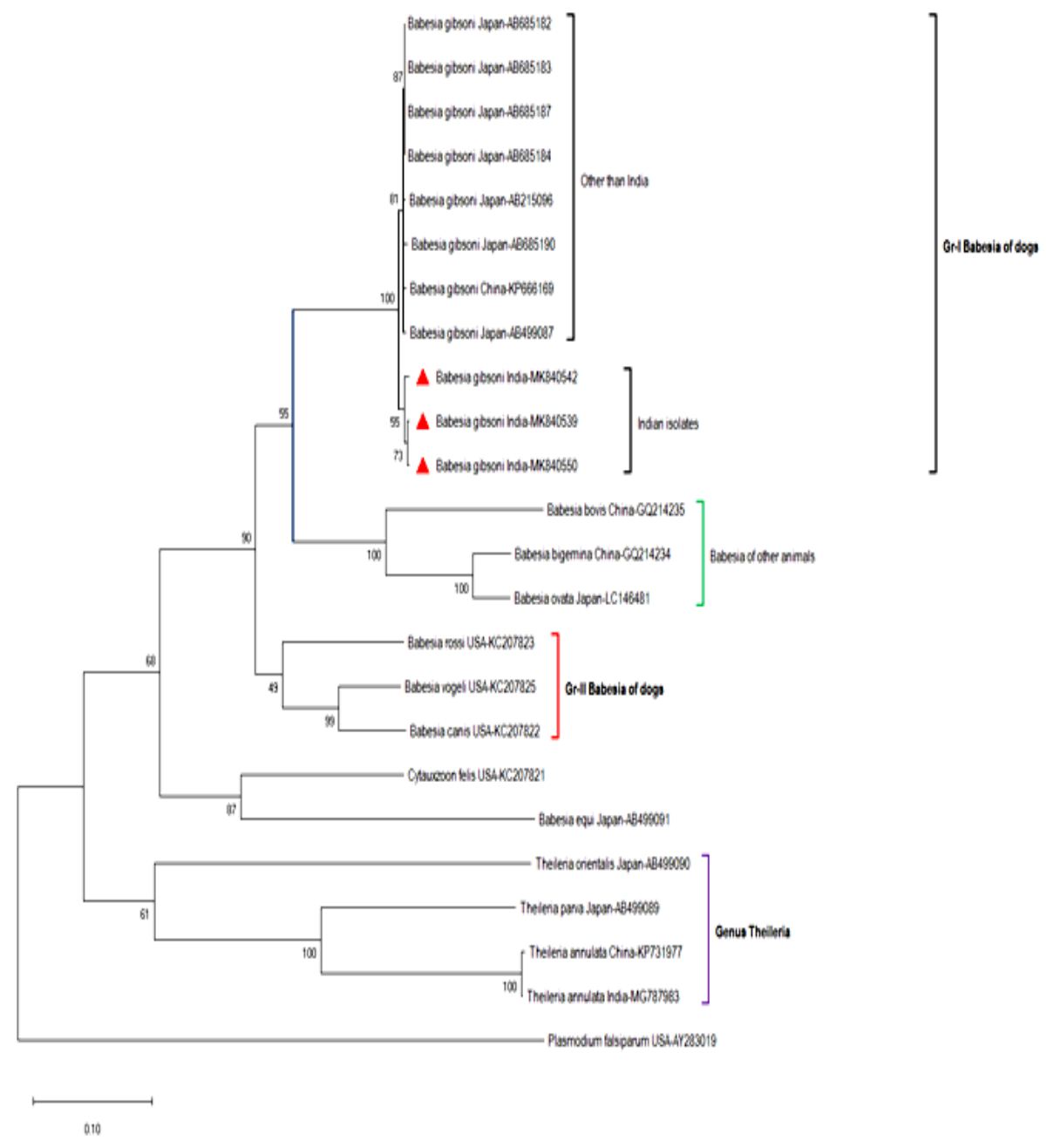

Figure 2 Maximum likelihood tree generated by complete cytochrome $b$ gene sequences showing the genetic relationship of the B. gibsoni isolates from India with other countries. Isolates for which the cytb gene obtained in this study are indicated by a triangle (Red)

were observed at positions 69 (A-G), 96 (G-T), $360(\mathrm{~A}-\mathrm{G}), 363$ (T-G), 430 (C-T), 504 (A-G), 615 (C-T), 658 (A-G), 726 (G-A), 810 (A-T), 907 (G-A) and 939 (A-G) when compared to standard (AB685190). Whereas, at amino acid level the variations were observed at 220 (I-V) and 303 (V-I) compared to standard (AB685190).

\subsection{Risk factors analysis}

The prevalence of $B$. gibsoni infection was not significantly associated with risk factors like age $\left(X^{2}=8.497, p=0.5804\right)$, breed $\left(X^{2}=17.31, p<0.5018\right)$, gender $\left(X^{2}=1.564 p<0.2111\right)$, fur length $\left(X^{2}=0.040, p<0.8409\right)$ and presence of tick $\left(X^{2}=2.919, p<0.0875\right)$ in present study population. However, the prevalence of $B$. gibsoni was higher in $>5-6$ years $(17.85 \%)$ age group dogs, followed by $>1-2$ years $(16.66 \%)$ and lower in above 10 years
(2.5\%) age group dogs (Table 1). The prevalence of B. gibsoni was highest in golden retriever $(25.8 \%)$ breed of dogs and lowest in beagle $(0.25 \%)$. The infection rate was higher in male $(13.11 \%)$ compared to female $(8.27 \%)$ dogs. The B. gibsoni infection significantly correlated with clinical sings of vomition $\left(X^{2}=4.673\right.$, $p=0.0306)$ and yellow coloured urine $\left(X^{2}=3.937, p=0.0472\right)$.

\section{Discussion and Conclusions}

Canine babesiosis is an emerging vector-borne haemoprotozoan disease of domestic and wild canids caused by Babesia gibsoni and B. vogeli. The disease is being reported from different states of India and is mainly based on clinical and microscopic examination. Even though few studies based on PCR have been carried out by targeting $18 \mathrm{~S}$ rRNA gene. The disadvantage is due to its very low copies of $18 \mathrm{~S}$ rRNA in the piroplasm genomes 
Table 1 Descriptive and statistical analysis of various characteristics related to dogs infected with B. gibsoni, detected by PCR

\begin{tabular}{|c|c|c|c|c|c|c|c|}
\hline Attributes & & $\mathrm{N}$ & $\mathrm{N}+$ & N- & $\%$ & $X^{2}$ & $\mathrm{P}$ \\
\hline \multirow{2}{*}{ Sex } & Male & 183 & 24 & 159 & 13.11 & \multirow{2}{*}{1.564} & \multirow{2}{*}{0.2111} \\
\hline & Female & 145 & 12 & 133 & 8.27 & & \\
\hline \multirow{2}{*}{ Fur length } & Small & 197 & 21 & 176 & 10.65 & \multirow{2}{*}{0.0403} & \multirow{2}{*}{0.8409} \\
\hline & Medium & 131 & 15 & 116 & 11.45 & & \\
\hline \multirow{2}{*}{ Fever } & Yes & 167 & 24 & 143 & 14.37 & \multirow{2}{*}{3.228} & \multirow{2}{*}{0.0724} \\
\hline & No & 161 & 12 & 149 & 7.45 & & \\
\hline \multirow{2}{*}{ Vomition } & Yes & 130 & 21 & 109 & 16.15 & \multirow{2}{*}{4.673} & \multirow{2}{*}{0.0306} \\
\hline & No & 198 & 15 & 183 & 7.57 & & \\
\hline \multirow{2}{*}{ Yellow coloured urine } & Yes & 49 & 10 & 39 & 20.40 & \multirow{2}{*}{3.937} & \multirow{2}{*}{0.0472} \\
\hline & No & 279 & 26 & 253 & 9.31 & & \\
\hline \multirow{2}{*}{ Presence of ticks } & Yes & 125 & 19 & 106 & 15.2 & \multirow{2}{*}{2.919} & \multirow{2}{*}{0.0875} \\
\hline & No & 203 & 17 & 186 & 8.37 & & \\
\hline
\end{tabular}

N: Number of dogs tested by PCR; $X^{2}$ : Chi-square test; P: $P$-value

(Criado et al., 2006) which makes sensitivity of the assay low. Therefore, the present study was carried out to develop PCR assay by targeting cytochrome $b$ of $B$. gibsoni as a diagnostic target, which is present in more copies in an organism. The primers were designed based on available sequences and PCR was first standardized with microscopic positive $B$. gibsoni samples.

The sensitivity of the cytb gene based PCR to detect $B$. gibsoni was $10^{-2}(0.5 \mathrm{ng} / \mu \mathrm{l})$ for blood $(50 \mu \mathrm{l})$ with a parasitaemia of $3.17 \%$. Whereas, with $18 \mathrm{~S}$ PCR assay the specific amplification was observed at lower template dilution of $10^{-1}(2.5 \mathrm{ng} / \mu \mathrm{l})$, which confirming the greater sensitivity of the cytb based PCR method than 18S. Similar results have been reported for B. bovis and B. bigemina (Salem et al., 1999) and for Theileria annulata detected to the dilution representing a parasitaemia of $10^{-4}$ based on PCR of cytb gene (Bilgic et al., 2010).

The prevalence of $B$. gibsoni by microscopic examination was reported at $9.75 \%$, which is more compared to earlier study in pet and stray dogs at the rate of $4.81 \%$ (Sahu et al., 2014). Whereas, few studies have reported higher prevalence rate of $31.37 \%$ (Mahalingaiah et al., 2017) and $35.13 \%$ (Laha et al., 2014). The varied prevalence rates might be attributed to vector and immune status of host and climatic conditions in different geographical regions (Mahalingaiah et al., 2017). In addition, the variation in sample size and type of case enrolled for study (Laha et al., 2014) might have contributed to higher prevalence rate compared to present study.

The PCR based prevalence $(10.97 \%)$ was higher compared to microscopic examination based prevalence of B. gibsoni in dogs. Similar finding have reported in the past (Inokuma et al., 2004;
Cardoso et al., 2016) PCR targeting 18S rRNA gene in comparison to microscopic examination. In contrast, studies by Jain et al. (2017) and Mahalingaiah et al. (2017) have reported $47.33 \%$ and $49.09 \%$ prevalence by PCR in India. Along with vector, environmental conditions, case definition and sample size, the lower prevalence rate in the study might be attributed to good immune status of the host, body condition and other management practices like hygienic rearing of pets, deworming, regular use of ectoparasiticides etc., as observed during clinical examination. The higher prevalence has been reported in young than old age dogs (Sahu et al., 2014; Mahalingaiah et al., 2017), similarly due to more number of old age dogs being enrolled during the study period might have also contributed to overall lower prevalence rate. However, there was no significant correlation between age and B. gibsoni infection. Similar to present finding, no association was established between presence of infection with breed and sex in many other studies (Senthil Kumar et al., 2009; Singh et al., 2014; Roopesh, 2017). The higher prevalence in male dogs is reported (Sahu et al., 2014) and authors attributed to hormonal changes and behaviour changes like roaming in search of mates, food and territory. But in this study even though there were no stray dog cases even then there was higher prevalence in males $(13.11 \%)$ which needs further investigations.

During the study period the overall prevalence of tick presence was recorded at $38.1 \%$. Even though there was no significant correlation between presence of ticks and disease, it is observed that the high prevalence in proportion to presence of tick (Abd Rani et al., 2011; Mahalingaiah et al., 2017; Roopesh, 2017). The clinical signs of vomition and yellow coloured urine correlated with B. gibsoni 
infection, whereas no association was found with fever as reported earlier (Miyama et al., 2005; Varshney et al., 2008).

To understand the molecular diversity of B. gibsoni in the region, three representative isolates were subjected for sequencing and phylogenetic analysis, which confirm all the three isolates as $B$. gibsoni (MK840539, MK840542 and MK840550). The B. gibsoni isolates from Indian origin grouped with isolates from Japan and China forming single group (Gr-I Babesia of dogs) indicating circulation of same genotype in Asian region. The similar grouping of all B. gibsoni isolates irrespective of country of origin and morphology and absence of differential biologic and immunologic features were observed in other studies targeting 18S rRNA and ITS1 (Criado-Fornelio et al., 2003; Bostrom et al., 2008; Mandal et al., 2014). The Indian isolates formed separate subgroup with in the $B$. gibsoni group of Asian genotype indicating circulation same clonally expanded single strain as was observed with 18S rRNA and ITS1 gene based phylogenetic analysis (Mandal et al., 2014).

In conclusion, B. gibsoni infection is highly prevalent in this region of country. The cytochrome $b$ gene based PCR found to be potential confirmatory diagnostic assay compared to conventional microscopy. None of clinical sings and host factors studied significantly correlated with presence of infection except vomition and yellow coloured urine, which make differential diagnosis difficult for clinician with other disease conditions. The cytb gene sequencing and phylogenetic revealed genetically similar B. gibsoni isolates are circulating in the region. The cytb gene can be useful molecular diagnostic and genetic marker, which needs further studies with more number of isolates from different regions of India.

\section{Acknowledgements}

The authors are thankful to the Director, ICAR-NIVEDI for providing necessary facilities and Vice-Chancellor, KVAFSU, Bidar and Dean, Veterinary College, Bengaluru for academic and research support.

\section{Conflict of interest}

All Authors declare that there is no conflict of interests that could possibly arise.

\section{References}

Abd Rani PAM, Irwin PJ, Coleman GT, Gatne M, Traub RJ (2011) A survey of canine tick-borne diseases in India. Parasites and Vectors 4:141.

Augustine S, Sabu L, Lakshmanan B (2017) Molecular identification of Babesia spp. in naturally infected dogs of Kerala, South India. Journal of Parasitic Diseases 41: 459-462.

Journal of Experimental Biology and Agricultural Sciences http://www.jebas.org
Beugnet F, Moreau Y (2015) Babesiosis. Scientific and Technical Review 34: 627-639.

Bilgic HB, Karagenc T, Shiels B, Tait A, Eren H, Weir W (2010) Evaluation of cytochrome $\mathrm{b}$ as a sensitive target for PCR based detection of T. annulata carrier animals. Veterinary Parasitology 174:341-347.

Bilwal AK, Mandali GC, Tandel FB (2017) Clinicopathological alterations in naturally occurring Babesia gibsoni infection in dogs of Middle-South Gujarat, India. Veterinary World 10:1227-1232.

Birkenheuer AJ, Levy MG, Breitschwerdt EB (2003) Development and evaluation of a seminested PCR for detection and differentiation of Babesia gibsoni (Asian Genotype) and $B$. Canis DNA in canine blood samples. Journal of Clinical Microbiology 41: 4172-4177.

Boozer AL, Macintire DK (2003) Canine babesiosis. Veterinary Clinics of North America: Small Animal Practice 33: 885-904.

Bostrom B, Wolf C, Greene C, Peterson DS (2008) Sequence conservation in the rRNA first internal transcribed spacer region of Babesia gibsoni genotype Asia isolates. Veterinary Parasitology 152: 152-157.

Cardoso L, Oliveira AC, Granada S, Nachum-Biala Y, Gilad M, Lopes AP, Sousa SR, Vilhena H, Baneth G (2016) Molecular investigation of tick-borne pathogens in dogs from Luanda, Angola. Parasites and Vectors 9: 252.

Conrad P, Thomford J, Yamane I, Whiting J, Bosma L, Uno T, Holshuh HJ, Shelly S (1991) Hemolytic anemia caused by Babesia gibsoni infection in dogs. Journal of American Veterinary Medical Association 199: 601-605.

Criado A, Martinez J, Buling A, Barba JC, Merino S, Jefferies R, Irwin PJ (2006) New data on epizootiology and genetics of piroplasms based on sequences of small ribosomal subunit and cytochrome b genes. Veterinary Parasitology 142: 238-247.

Criado-Fornelio A, Gónzalez-del-Río MA, Buling-Saraña A, Barba-Carretero JC (2003) Molecular characterization of a Babesia gibsoni isolate from a Spanish dog. Veterinary Parasitology 117:123-129.

Fukumoto S, Suzuki H, Igarashi I, Xuan X (2005) Fatal experimental transplacental Babesia gibsoni infections in dogs. International Journal of Parasitology 35: 1031-1035.

Inokuma $\mathrm{H}$, Yoshizaki $\mathrm{Y}$, Matsumoto $\mathrm{K}$, Okuda $\mathrm{M}$, Onishi T, Nakagome K, Kosugi R, Hirakawa M (2004) Molecular survey of Babesia infection in dogs in Okinawa, Japan. Veterinary Parasitology 121: 341-346. 
Jain KJ, Lakshmanan B, Syamala K, Praveena JE, Aravindakshan $\mathrm{T}$ (2017) High prevalence of small Babesia species in canines of Kerala, South India. Veterinary World 10: 1319-1323.

Kumar S, Stecher G, Li M, Knyaz C, Tamura K (2018) MEGA X: Molecular Evolutionary Genetics Analysis across computing platforms. Molecular Biology and Evolution 35: 1547-1549.

Laha R, Bhattacharjee K, Sarmah PC, Das M, Goswami A, Sarma D, Sen A (2014) Babesia infection in naturally exposed pet dogs from a northeastern state (Assam) of India: detection by microscopy and polymerase chain reaction. Journal of Parasitic Diseases 38: 389-393.

Mahalingaiah MKC, Asoor M, Thimmaiah RP, Narayanaswamy HD, Mukartal SY, Elattuvalappil AM, Chikkahonnaiah N, Gupta S, Singh S (2017) Prevalence of canine babesiosis in different breeds of dogs in and around Bengaluru. Advances in Animal and Veterinary Science 5: 140-144.

Mandal M, Banerjee PS, Garg R, Ram H, Kundu K, Kumar S, Kumar GV (2014) Genetic characterization and phylogenetic relationships based on 18S rRNA and ITS1 region of small form of canine Babesia spp. from India. Infection Genetics Evolution 27: 325-331.

Miyama T, Sakata Y, Shimada Y, Ogino S, Watanabe M, Itamoto K, Okuda M, Verdida RA, Xuan X, Nagasawa H, Inokuma H (2005) Epidemiology survey of Babesia gibsoni infection in dogs in eastern Japan. The Journal of Veterinary Medical Science 67: 467-471.

Roopesh MP (2017) Epidemiological studies on babesiosis in dogs in Bengaluru district. M.V.Sc. Thesis, submitted to KVAFSU, Bidar.
Sahu A, Mohanty B, Panda MR, Sardar KK (2014) Incidence of Haemoprotozoan Parasites in Dogs in and around Bhubaneswar, Odisha. Indian Veterinary Journal 91: 93-95.

Salem GH, Liu X, Johnsrude JD, Dame JB, Roman-Reddy G (1999) Development and evaluation of an extra chromosomal DNA-based PCR test for diagnosing bovine babesiosis. Molecular and Cellular Probes 13: 107-113.

Senthil Kumar K, Vairamuthu S, Kathiresanl D (2009) Prevalence of Haemoprotozoans in canines in Chennai City. Tamilnadu Journal of Veterinary and Animal Science 5: 104-108.

Singh A, Singh H, Singh NK, Singh ND, Rath SS (2014) Canine Babesiosis in Northwestern India: Molecular Detection and Assessment of Risk Factors. BioMed Research International. doi: $10.1155 / 2014 / 741785$.

Solano-Gallego L, Sainz A, Roura X, Estrada-Peña A, Miró G (2016) A review of canine babesiosis: the European perspective. Parasites and Vectors. doi: 10.1186/s13071-016-1596-0.

Suh GH, Ahn KS, Ahn JH, Kim HJ, Leutenegger C, Shin S (2017) Serological and molecular prevalence of canine vectorborne diseases (CVBDs) in Korea. Parasites and Vectors. doi: 10.1186/s13071-017-2076-x.

Varshney JP, Deshmukh VV, Chaudhary PS (2008) Multisystem effects of canine babesiosis and management of critical cases. Intas Polivet 9: 281-287.

Wadhwa DR, Pal B, Mandial RK, Adarsh Kumar, Agnihotri RK (2011) Clinical, haemato-biochemical and therapeutic studies on canine babesiosis in Kangra Valley of Himachal Pradesh. Journal of Veterinary Parasitology 25: 39-41. 